\title{
A study on brand commitment and brand trust towards brand loyalty of branded laptop in Indonesia
}

Ida Hidayanti

Economics and Business Faculty, Diponegoro University, Semarang. Indonesia

Nuryakin

Management Department Universitas Muhammadiyah Yogyakarta, Indonesia

Naili Farida

Economics and Business Faculty Diponegoro University, Semarang. Indonesia

\section{Key words}

Brand experience, brand satisfaction, brand trust, brand commitment, brand loyalty.

\begin{abstract}
The aim of this study is to investigate the effects of brand experience and brand trust to enhancing brand commitment and brand loyalty. The data of the study collected by survey method. The sample in this research is the students from three cities in Indonesia as Yogyakarta, Semarang and Jakarta. The analysis of this research uses SEM. The results of testing four hypotheses of the study as significant. Brand experience support to brand commitment. Brand trust support to brand commitment. Brand commitment support on brand loyalty. The unit analysis is also a less in this study due to the current laptop products are no longer a luxury product but they shifts as commodity that are commonly used by university students.
\end{abstract}

Corresponding author: Nuryakin

Email addresses for corresponding author:nuryakin@umy.ac,id

First submission received: $23^{\text {rd }}$ August 2017

Revised submission received: $6^{\text {th }}$ February 2018

Accepted: $27^{\text {th }}$ February 2018

\section{Introduction}

Brand is an important asset of a business and it can be a relationship of business and consumers. Brand is a description of product and service type to business offering. The previous study describe brand reputation will be effect on performance both in financial and nonfinancial performance, the actually makes the important of brand management (Abimbola \& Kocak, 2007). A high tech product is considered not to be able to create a significant different compared to competitors because consumers are experiencing shifts of need and wants at present (Ferrinadewi, 2008). The shifting need and want of consumer demands marketers to create a product that is able to provide value functionally, emotionally and expressively.

Brand commitments define a consumer act of repossessing a brand that is creating suitability to need and desire. A brand of laptop product will be successful if it maintains brand positioning that will be associated as a good brand. A brand has inherent brand image among the public, always initiate the digital age with technology innovations keeping up with development of the era, offering high quality product, attractive product design and implement differentiation and diversification of products, set varied and affordable prices. Types of consumers should be understood in order to create brand commitment. Tanford, Raab, and Kim (2011) asserts brand commitment can be grouped into two types, namely affective commitment and value commitment. The value commitment tends to be more sensitivity to price and indicates low involvement of consumer, while affective commitment had higher tendency toward product and price differentiation and high involvement.

The study of brand experience will be interesting because there are contradictory results the role of brand experience to brand commitment as expressed Delgado-Ballester and Aleman (2001). Furthermore, Delgado-Ballester and Aleman (2001) explain that trust is a mediating variable of relationship between satisfaction and commitment, which means that marketers must create consumer 
involvement with brand by providing an enjoyable experience so that frequency of interaction with the brand will long runs. Finally, it will be create confidence in quality, reputation and convenience in using the product brand. Brand experience is conceptualized as sensation, feeling, cognition, and behavioral responses induced by stimuli related to a brand that is part of the brand such as he design and identity, packaging, communication, and the environment (Brakus, Schmitt, \& Zarantonello, 2009).

The business competition process is increasingly sharpening, consumer preferences and behavior change; information technology develops rapidly in business to focus on higher response to customer satisfaction (Nuryakin \& Farida, 2016). Brand competition of PC today is increasingly competitive, manufacturers are trying to meet needs and wants of consumers by offering a variety of products with a lot of choices based on specifications, color, size and price. An increasingly greater bargaining power of consumer encourages every company to put its orientation on customer satisfaction as their primary goal. Type or brand is a name of a product released by a company. Laptops such as HP, Compaq, Lenovo, Sony Vaio, Dell, Apple, Asus, Axio, Acer, Samsung and Toshiba are some brands with quality and good name in development laptop products.

Brand trust is dominant factors to a role and enhance of consumer loyalty with a specific brand. According to Ferrinadewi (2008) consumer's trust to a brand can be obtained product if a marketer create and maintenance a positive emotional relationship with consumer. If consumers possessed an positive on a brand, so their tendency to be satisfied with the brand turns on the purchase repeated (Nuryakin \& Farida, 2016). This positive emotional relationship should be long term develop, but it should be consistently and persistently. Marketers must be able to create consumer trust in a brand to create loyalty, because consumer loyalty to a brand cannot be descript without consumer's trust in the brand. Based on the background to the research, this study is to examine mediating effect of brand commitment to enhance brand experience and brand loyalty. The aim of this study is to investigate the effects of brand experience and brand trust to enhancing brand commitment and brand loyalty.

\section{Literature Review \\ Brand experience}

Brand experience can define personal activities to response a product or service. The partial experience involves is all individual activities. For example, a marketers need to develop and control environment situation for customer and what the achieve customer activities. In generally study, the experience is not generated on personality but it is persuade, psychologically. We explain experience is something that had happened unintentional. Brand experiential can explain on ten involve elements of sensory, emotional, cognitive, behavioral and relational values and a functional value. In this study, brand only a intangible activities, but also tangible (Schmitt, 1999). The concept of brand experiences can reflect an affective, cognition, and behavioral response and supporting on brand associated with in a design, brand identity, labelling, communication, and environment (Brakus et al., 2009). Brand experience emphasizes experiences of customers subjectively (Brakus et al., 2009), while emotional attachment to brands explains emotional attachment of customers. There has only research combining these two concepts in a more comprehensive model to explain consumer brand loyalty.

\section{Brand Commitment}

Morgan and Hunt (1994) Defines commitment as "an enduring desire to maintain a value of relationship. Delgado-Ballester and Aleman (2001) States that trust is a variable mediating relationship between satisfaction and commitment. More there, the meaning that if level of satisfaction with a brand cannot make a consumer to be committed directly to use the brand, but commitment can through a high level trust based on experience while using the branded product. The high level of brand satisfaction and accompanied by trust of the consumer in the brand it will encourage people to a commitment. Hess and Story (2005) Investigate a correlation of consumer satisfaction and commitment in retail services. The research shown if consumers' satisfaction exceeded their expectations, they will have a repeat buying. Customer satisfaction is not enough, but the level of consumer trust in a brand will establish a commitment to the brand friendly.

Customer satisfaction exceeds expectation; it creates a construct of trust in quality of service perceived. Sahin, Zehir, and Kitapçı (2011) Investigates brand trust, brand experience and brand 
satisfaction to enhance brand loyalty. Eric Aysel, Sevtap, Candan, and Hatice (2012) argued that a brand satisfaction and brand trust is a reflect on affective commitment. The affective commitment is presented a repurchase intention and loyalty. However, direct effect of commitment on the repurchase intention to achieve brand loyalty not supported. Furthermore, Sahin, Kitapci, and Zehir (2013) investigate a brand trust is a mediating variable of relationship between satisfaction and commitment. The results of this study indicated that the higher satisfaction of a partial will shape trust to enhance commitment.

\section{Brand Trust}

Luarn and Lin (2003) Studies described trust is a specific belief in integrity, and competency. Trust in a brand is willingness to belief in the brand at all costs because of existing hope promised by the brand in delivering positive outcomes for consumers. Trust of brand has a aspects guiding consumers in a decision making to product buying. Brand trust is a willingness of consumers to belief in the brand at all risks, because there is a hope the brand to give a positive value (Lau and Lee (1999).

Furthermore, in this study we investigation on study Lau and Lee (1999) that the brand trust is an antecedent of brand loyalty. Brand characteristics, firm characteristics, and brand-consumer characteristics value on brand trust. Thus, to create a loyalty, manufactures must develop consumer loyalty. The many study stated that the brand trust significantly affects brand loyalty. The result is supported by previous findings (Morgan \& Hunt, 1994) namely trust creates an exchange relationship between brands and customers. A study of Hee Jung and Myung Soo (2012) found that brand trust not effect on brand loyalty.

\section{Brand Loyalty}

Brand loyalty can be measure of customer association to useful by a brand product evaluation. Brand loyalty is commitment of customer to a given brand product from the loyalty of a positive attitude toward the brand (Morgan and Hunt 1994). Aaker (1997) explained brand loyalty is a measure consumer attractiveness with a brand. The measurement brand describes a possibility that a loyal customer will not easily switch to another brand although whatever happens with the brand. This means that the higher loyalty of a customer loyalty to a brand, the reduced vulnerability of the customer group from threat and attack of competitor. According to Aaker (1997) brand loyalty can be divided into several levels, :

1. Switcher is defined as basic loyalty because a customer often makes brand shift and tend to be customer with lack of loyalty. Such customers are characterized by brands product purchasing.

2. Habitual Buyer is meant a customer who makes a purchase based on habit due to the level of loyalty measured is an element of satisfaction with the product brand.

3. Satisfied buyer is defined as a customer of brand who is satisfied with the switching costs providing substantial benefits to compensate.

4. Likes the brand is interpreted as a buyer who loves a brand because of emotional touch. A brand is associated as a symbol, impression of high quality and range of experience that is perceived personally or by other relatives.

\section{Hypothesis Development}

\section{The Relationship between Brand Experiences on Brand Commitment}

Brand experience can be define personal activities to response a product or service. For example, a marketers need to develop and control environment situation for customer and what the achieve customer activities. In generally study, the experience is not generated on personality but it is persuade, psychologically. We explain experience is something that had a happened unintentional. Brand experiential can explain on ten involve elements of sensory, emotional, cognitive, behavioral and relational values and a functional value (Schmitt, 1999).

Morgan and Hunt (1994) Define commitment as "an enduring desire to maintain a value of relationship. Delgado-Ballester and Aleman (2001) asserts that trust is a variable mediating relationship between satisfaction and commitment. Moreover, the meaning that if level of satisfaction with a brand cannot make a consumer to be committed directly to use the brand, but commitment can through a high level trust based on experience while using the branded product.

Brand experience is a conceptual, cognition, and behavioral response that associated of a design and identity, labelling, communication, and environment (Brakus et al., 2009). Hee Jung and Myung Soo (2012) explained brand experience as a affected significantly on brand commitment. The findings shown 
affective brand experience and behavioral brand experience has a positive effect on brand commitment. It means that when a consumer experience in both perceived knowledge and behavior with the needs and expectations, to commit a used a brand. Based on literature review and previous study, we proposes: Hypothesis 1: brand experience has positive effect on brand commitment.

\section{The Relationship between Brand trust and Brand Commitment}

Luarn and Lin (2003) described trust is a specific belief in integrity, and competency. Trust in a brand is willingness to belief in the brand at all costs because of existing hope promised by the brand in delivering positive outcomes for consumers. Trust of brand has an aspects guiding consumers in a decision making to product buying. The effort of brand commitment cannot be separated from cognitive and affective aspects. Brand commitment is an ability a consumer's to commit and to leave a brand. Delgado-Ballester and Aleman (2001) Explained that brand trust is affecting on brand commitment. Chaudhuri and Holbrook (2002) Described that a relational exchange and analysis for determining the role of brand trust and brand effect on brand commitment. The findings showed the brand trust effects on brand commitment, to improve performance of the brand. Therefore, brand is very importance to enhance performance (Nuryakin \& Sugiyarti, 2018).

The similar study, Sanchez-Franco (2009) suggesting that brand trust had positive effect on brand commitment. Moreover, Munyaradzi W. Nyadzayo , J.Matanda, and Ewing (2014) described a relationship of brand commitment significant affecting on brand image. This shows that confidence of an individual on experience with a brand would create a positive image. Since as we know that an image can be interpreted as a combination of a number of thoughts, associations an individual relationship with a product, brand, company, or even a person. Brand image is always associated with the trust of expectation of creating a corporate reputation. The findings were consistent with Erkmen and Hancer (2015) that brand trust has effect on brand commitment. It means that when an individual has trust in a brand, customer will develop trust to commit. Trust is a strong predictor in determining on commitment. Customers who already have trust, they will have commit, a higher of brand loyalty. Based on literature review and previous study, we proposes:

Hypothesis2: brand trust has positive effect on brand commitment.

\section{The relationship between Brand Trust and Brand loyalty}

Lau and Lee (1999) argue that brand loyalty cannot be achieved with other measure, but how a relationship between brand trust and brand loyalty. Moreover, brand trust is very important and one of the key factors to developing brand loyalty. In the study of brand satisfaction, brand trust and brand loyalty. For example Horppu, Kuivalainen, Tarkiainen, and Ellonen (2008) explain the features effect on the brand purchase online and offline. The findings indicated that website trust for online purchase will affect a need to repurchase and it will be create loyalty.

Chaudhuri and Holbrook (2001) describe brand loyalty will be created of brand trust and effect of brand on customer involvement through hedonic and utilitarian values of a product. The categories of a product brand create value can enhance target manufacturers. At hedonic level, customer end to buy branded products because of element of pleasure, want to see when using the brand. While, at utilitarian level, customer make to see more on use or function of a product so that they are more sensitive to price. Price is largely affecting association of customer to quality level of a branded product.

Sahin et al. (2011) Explain that the higher brand trust, the higher brand loyalty. In others study, Laroche, Habibi, Richard, and Sankaranarayanan (2012) suggested that brand trust had effect on brand loyalty. The others result was presented by Hee Jung and Myung Soo (2012) that brand trust had effect on brand loyalty. It means that the higher trust of a personal in a brand trust, the higher tendency of an individual to have the brand continuously and ultimately, it produces brand loyalty. Based on review of the literature and previous study, we present proposes hypothesis as follow:

Hypothesis 3: brand trust has positive effect, the higher brand loyalty.

\section{The relationship Between Brand Commitment and Brand loyalty}

Brand loyalty can be created if customers develop brand trust (Ferrinadewi (2008). Customer trust will be created if customer using experience on the brand. Tsai (2011) Suggested that antecedents of brand loyalty on brand commitment, brand trust, brand satisfaction, and the relationship of trust and brand 
attachment. The findings demonstrated brand commitment had effect on brand loyalty. It means that the higher action of using a brand, the greater knowledge of brand design, quality, reputation and excellence a customer obtains and then, it will form a need to make commitment to use the brand again, and ultimately, it create brand loyalty.

Hee Jung and Myung Soo (2012) investigate brand commitment effect on brand loyalty. The research shows that the higher brand trust of an individual, the higher brand loyalty. When an individual has a high brand loyalty, then will try to use the brand continuously by competitive brands. Based on literature and previous study, we proposes:

Hypothesis 4: brand commitment has positive effect on brand loyalty.

\section{Research Method and Measures}

Data collected with a survey method and distributing questionnaire with open and closed statement of perceived of branded laptop product. The sample of the research is 200 respondents representing the three cities and the respondents are taken with a purposive sampling method. The respondents are male and female students in higher education in Indonesia. The hypothesis is tested using Structural Equation Modelling (SEM) software. All the variables in this research, i.e. brand experience, brand trust, brand commitment and brand loyalty, were measured with questionnaire by using likert-scale with answer scale 1-5. The scale represented the rating from 'strongly disagree' to 'strongly agree'.

\section{Screening Data}

The sample in this research was the students in three colleges in Indonesia, namely: Yogyakarta, Semarang and Jakarta. These three cities are selected because they are known city of higher institution students. Total respondents were as many as 200 Students. Purposive sampling was used to collect sample of this research. The total respondents in this study was 200 who were students of three colleges in Semarang, Yogyakarta and Jakarta. Based on the survey distributed, 197 questionnaires were filled completely. After screening and normality data the total remaining sample of this research was 184 respondents.

\section{Confirmatory Factor Analysis and Reliability}

Based on confirmatory factor analysis, we observed validity and reliable indicators in full model testing of SEM. Validity is examined by using face validity that us a basic test model of a content validity indicating that the items used to measure a concept (Sekaran, 2003). Validity of instruments is examined by using Confirmatory Factor Analysis for items of questionnaire assisted by SPSS16 software (Wulandari, Djastuti, \& Nuryakin, 2017). The value of rule validity will be used for CFA should be $\geq 0.4$ (Hair, C.Black, Babin, \& Anderson, 2010). Reliability test in this models to measure and reflecting in construct, thus providing a consistent measurement on each item in the instrument (Sekaran, 2003). Item consistency of questions of the questionnaire is tested with Cronbach Alpha.

The rule of value used for Cronbach's Alpha value must be more than 0.7, even though value of 0.6 is acceptable (Hair et al., 2010). Cronbach's Alpha formula is used to test reliability of the questionnaire instrument assisted by SPSS 16 software.

The instrument testing used the validity test, some indicators were eliminated because their values did not required factor loading. Some items selected had validity of above 0.70 . Its indicates the instrument is actually measuring actual model (Sekaran, 2003). Therefore, reliability test shown consist of the measurement scale. All variables were declared reliable because they had Cronbach's Alpha more than 0.7. The results of this model can be demonstrated in table of validity and reliability testing. Moreover table 1 shown the analysis factors of indicator and construct.

Tabel. 1. Measurement scales, confirmatory factor analysis results, and Cronbach's Alpha Coefficient

\begin{tabular}{|l|c|}
\hline Constructs and Measurement Item & $\begin{array}{c}\text { Standardized Loadings } \\
\text { Factor }\end{array}$ \\
\hline Brand Experience (Cronbach's a = 0.846) & 0.782 \\
The branded laptop is attractive uniquelly (BE1). & 0.771 \\
The branded laptop is easily to use (BE2). & 0.760 \\
The branded laptop has excellent and very useful additional features (BE3). & \\
\hline
\end{tabular}




\begin{tabular}{|l|c|}
\hline The branded laptop is preferred (BE4) & 0.736 \\
\hline Brand Trust (Cronbach's a = 0.834) & 0.775 \\
The branded laptop is reliable (BT1). & 0.697 \\
The branded laptop is trustworthy (BT2). & 0.802 \\
The branded laptop has high reputation (BT3). & 0.716 \\
Innovation of the branded laptop is always up-to- date (BT4). & 0.723 \\
\hline Brand commitment (Cronbach's a =0.831) & 0.776 \\
Good quality LCD (BC1). & 0.713 \\
Use the branded laptop gives prestige value (BC2). & 0.767 \\
I will buy the branded laptop because its various type and long-lasting touch & \\
(BC3). & 0.858 \\
The branded laptop is the best value other brands (BC4). & 0.850 \\
\hline Brand loyalty (Cronbach's a = 0.885) & 0.835 \\
The branded laptop provides varied prices and types (BL1). & \\
Good service support for maintenance (BL2). & \\
The branded laptop has strength image (BL3). & \\
\hline
\end{tabular}

\section{Result and Discussion}

The analysis of this study using confirmatory factor analyze (CFA) to investigate indicator and construct. Measurement model and fit model to define latent constructs, and a full model of SEM can be analyzed. The empirically model test using Structural Equation Modeling. The model indicate Chisquare $=124.044$ with probability value of 0.004 at the Degree of Freedom of 85; GFI=0.923, AGFI=0.892 and TLI $=0.963$, while value of RMSEA $=0.050$. The result of the model is a Fit. Based on statistically analysis the results of this study indicate conformity with the required standard values. As shown in Figure 2 the results of the Full Analysis Model

\section{Figure 2. The results of Full Model Analysis}

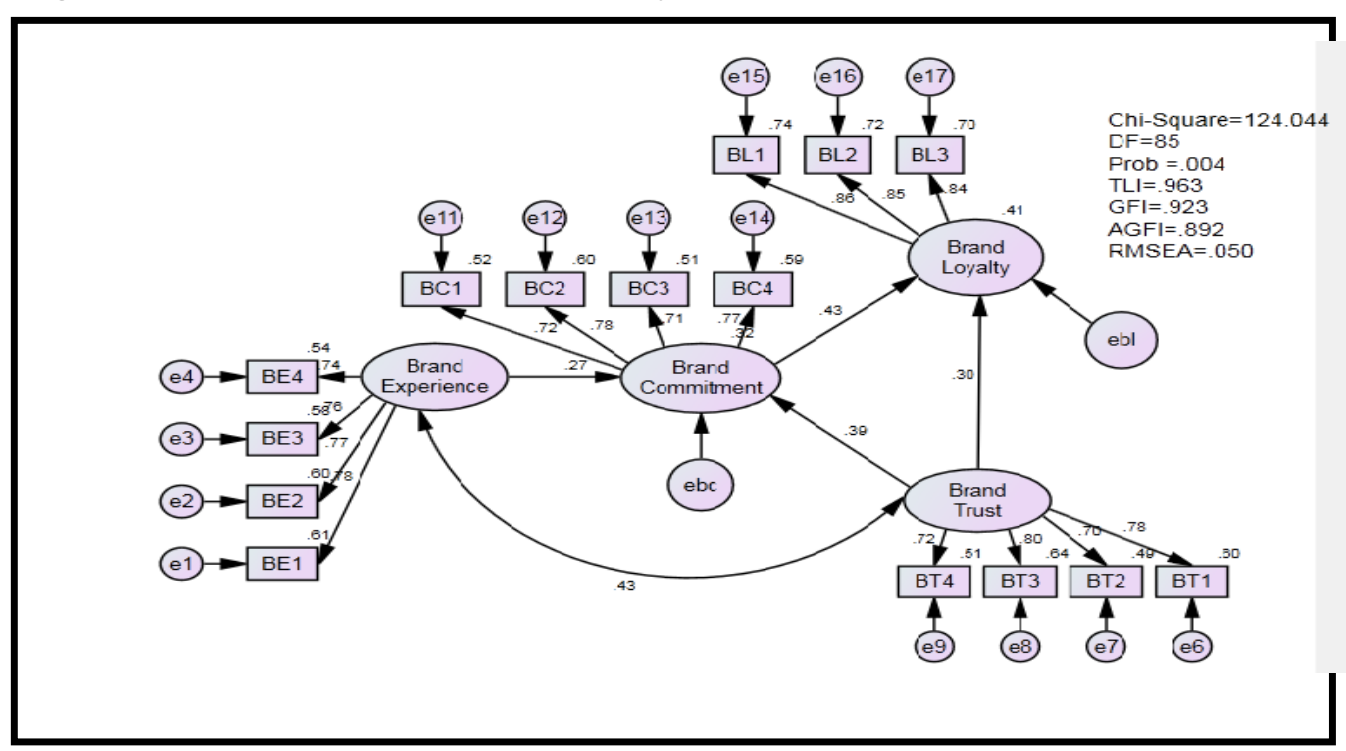

The framework is explained in the context of full model analysis in the following subsections with in regression weights. There are four hypotheses are accepted, hypothesis 1 until 4 is significant. Consequently, brand loyalty will be created. The study is consist of Erkmen and Hancer (2015) theory that if a person have trust, she will tend to have a commitment to repurchase intention. Brand experience affects brand commitment. It means that experience will show whether quality of a brand is consist has been communicated by advertisements or information obtained from a variety of references. If perceived experience about quality of a product brand is high, it will create trust in reputation of the brand. 
Laptop product is a superior product item but it has a daily commodity and consumption using product activity. Customers want to buy a laptop will a variety seeking information about specifications, functions, brands, designs, prices, and advance. Then, these attributes will be evaluated by considering advices from reference or family. Therefore, they come to retail and the choice of brands available. The effect of the retail will be able to affect the choice of laptop brands. The result of this hypothesis is supported by the open statement on the questionnaire which respondents to purchase intention. However, if they have a variety seeking information to choose, they will have preference of brands with prestige value, for example in Apple, Sony Vaio, Fujitsu.

Hypotheses 2 were supported. The result indicate that brand trust has a significant effect on brand commitment. It means that the higher trust of consumers towards a brand will induce action of higher involvement the brand in the future. Hypothesis 3 indicates brand trust has a significant effect on brand loyalty. It means that the higher trust of an individual with a particular brand will create brand trust in the brand, a loyalty the brand, it will affect the brand trust to brand loyalty.

Hypothesis 4 indicates brand commitment has a significant effect on brand loyalty. Its means that the higher brand commitment an individual can enhance brand loyalty of laptop product because it produces higher loyalty than expected one, it will create a brand commitment to enhance brand loyalty. The results consist with study of (Asadollahi, Jani, Mojaveri, \& Allahabadi, 2012; Delgado-Ballester \& Aleman, 2001).

Table 2. Line Test Results Coefficient: brand experience, brand trust, brand commitment and brand loyalty.

\begin{tabular}{|c|c|c|c|c|c|}
\hline Hypothesis & & $\begin{array}{c}\text { Standardized } \\
\text { path } \\
\text { coefficients }\end{array}$ & $\overline{t \text { value }}$ & Prob. & Result \\
\hline $\mathrm{H} 1$ & $\begin{array}{l}\text { Brand experience } \rightarrow \text { Brand } \\
\text { commitment }\end{array}$ & 0.255 & 2.968 & 0.003 & Significant \\
\hline $\mathrm{H} 2$ & Brand trust $\rightarrow$ Brand commitment & 0.376 & 4.001 & 0.000 & Significant \\
\hline H3 & Brand trust $\rightarrow$ Brand loyalty & 0.417 & 3.330 & 0.000 & Significant \\
\hline $\mathrm{H} 4$ & $\begin{array}{l}\text { Brand commitment } \rightarrow \text { Brand } \\
\text { loyalty }\end{array}$ & 0.615 & 4.558 & 0.000 & Significant \\
\hline
\end{tabular}

Note: *Significant at $\mathrm{p} \leq 0.05$; if $(\mathrm{t}) \geq 1.96$

\section{Conclusion and Limitation}

The analysis of this study uses structural equation modelling with AMOS Program. This study develops of four hypotheses. The research shown all hypotheses were supported. Hypothesis 1 states that brand experience has significant effect on brand commitment. Hypothesis 2 states that brand trust has significant effect on brand commitment. Hypothesis 3 states that brand trust has significant effect on brand loyalty. Hypothesis 4 states that brand commitment has significant effect on brand loyalty.

Business can pay attention which consumer will be targeted, since there are two types of consumers e.g. consumers with brand loyalty and price loyalty. Consumers who are loyal to the price of a product will look at product based on functional aspect and they do not think of emotional and expressive aspects. Finally, consumers who are loyal to a brand and prefer a product with recognize reputation. Since price determines level of quality a product for switching customer.

This study explains several conceptual and contextual in a future research. The Structural Equation Models is an analysis that had not shown many indicators and constructs that should be eliminated, because a loading factor values were lower than 0.7. It means that the proposed indicator is not measure the construct.

\section{Managerial Implication}

The contribution of the study is to examination the role of brand experience and brand trust to enhancing brand commitment and brand loyalty. The recommendation for a future research should be focus and more attention to aspects of content and context. The unit analysis is also a less in this study due to the current laptop products are no longer a luxury product but they shifts as commodity that are commonly used by university students. 


\section{Reference}

Aaker, J. L. (1997). Dimensions of Brand Personality. Journal of Marketing Research, 34(4), 347-356.

Abimbola, T., \& Kocak, A. (2007). Brand, organization identity and reputation SMEs as expressive organizations. Qualitative Market Research: An International Journal of Business and Management, Vol. 10 No. 4, pp. 416-430. doi: 10.1108/13522750710819748

Asadollahi, A., Jani, M., Mojaveri, P. P., \& Allahabadi, F. B. (2012). Investigating the Effect of Brand Satisfaction, Brand Trust and Brand Attachment on Purchase Behavior of Customers. Research Journal of Applied Sciences, Engineering and Technology 4(17), 3182-3187.

Brakus, J. J. s., Schmitt, B. H., \& Zarantonello, L. (2009). Brand Experience:What Is It? How Is It Measured? Does It Affect Loyalty? Journal of Marketing, 73, 52-68.

Chaudhuri, A., \& Holbrook, M. B. (2001). The Chain of Effects from Brand Trust and Brand Affect to Brand Performance: The Role of Brand Loyalty. Journal of Marketing, 65, 81-93.

Chaudhuri, A., \& Holbrook, M. B. (2002). Product-class effects on brand commitment and brand outcomes:

The role of brand trust and brand affect. Brand Management, 10(1), 33-58.

Delgado-Ballester, E., \& Aleman, J. L. M. (2001). Brand trust in contex of customer loyalty. European Journal of Marketing, 15(11/12), 1238-1258.

Eric Aysel, Sevtap, U., Candan, B. F., \& Hatice, Y. (2012). The effect of brand satisfaction, trust and brand commitment on

loyalty and repurchase intentions. Procedia - Social and Behavioral Sciences 58, 1395 - 1404.

Erkmen, E., \& Hancer, M. (2015). Linking brand commitment and brand citizenship behaviors of airline employees: "The role of trust". Journal of Air Transport Management 42, 47-54.

Ferrinadewi, E. (2008). Merek dan Psikologi Konsumen Implikasi pad Strategi Pemasaran. Yogyakarta: Graha Ilmu.

Hair, J. F., C.Black, W., Babin, B. J., \& Anderson, R. E. (2010). Multivariate Data Analysis (Vol. Seventh Edition): Prentice Hall Upper Saddle River New Jersey

Hee Jung, L., \& Myung Soo, K. (2012). The effect of brand experience on brand relationship quality. Academy of Marketing Studies Journal, 16(1), 87-98.

Hess, J., \& Story, J. (2005). Trust-based commitment: multidimensional

consumer-brand relationships. Journal of Consumer Marketing, 22(6), 313-322.

Horppu, M., Kuivalainen, O., Tarkiainen, A., \& Ellonen, H.-K. (2008). Online satisfaction, trust and loyalty, and the impact of the offline parent brand. Journal of Product \& Brand Management, 17(6), 403-413.

Laroche, M., Habibi, M. R., Richard, M.-O., \& Sankaranarayanan, R. (2012). The effects of social media based brand communities on brand community markers, value creation practices, brand trust and brand loyalty. Computers in Human Behavior 28, 1755-1767.

Lau, G. T., \& Lee, S. H. (1999). Consumers' Trust in a Brand and the Link to Brand Loyalty. Journal of Market - Focused Management, 4(4), 341.

Luarn, P., \& Lin, H.-H. (2003). A Customer Loyalty Model for E-service Context. Journal of Electronic Commerce Research, 4(4), 156-167.

Morgan, R. M., \& Hunt, S. D. (1994). The Commitment-Trust Theory of Relationship Marketing. Journal of Marketing, 58, 20-38.

Munyaradzi W. Nyadzayo , J.Matanda, M., \& Ewing, M. T. (2014). The impact of franchisor support, brand commitment, brand citizenship behavior, and franchisee experience on franchisee-perceived brand image. Journal of Business Research $x x x$ (2014) $x x x-x x x, x x x, 1-9$.

Nuryakin, \& Farida, N. (2016). Effects of Convenience Online Shopping and Satisfaction on RepeatPurchase Intention among Students of Higher Institutions in Indonesia. Journal of Internet Banking and Commerce, vol. 21, no. 2.

Nuryakin, \& Sugiyarti, G. (2018). Developing customer orientation to enhancing salesperson performance. Journal of Business and Retail Management Research (JBRMR), Vol. 12 Issue 2, pg. 143-150.

Sahin, A., Kitapci, H., \& Zehir, C. (2013). Creating Commitment, Trust and Satisfaction for a Brand: What is 
the Role of Switching Costs in Mobile Phone Market? Procedia - Social and Behavioral Sciences 99, 496 - 502.

Sahin, A., Zehir, C., \& Kitapçı, H. (2011). The Effects of Brand Experiences, Trust and Satisfaction on Building Brand Loyalty; An Empirical Research On Global Brands. Procedia Social and Behavioral Sciences 24, 1288-1301.

Sanchez-Franco, M. J. (2009). The Moderating Effects of Involvement on the Relationships Between

Satisfaction, Trust and Commitment in e-Banking. Journal of Interactive Marketing 23, 247-258.

Schmitt, B. H. (1999). Experiential Marketing. Joumal of Marketing Management 15, 53-67.

Sekaran, U. (2003). Research Methods forBusiness: A Skill Building Approach (4 ed.). New York: ed., New York: John Wiley \& Sons, Inc.

Tanford, S., Raab, C., \& Kim, Y.-S. (2011). The Influence of Reward Program Membership and Commitment on Hotel Loyalty. Journal of Hospitality \& Tourism Research 35(3), 279-307.

Tsai, S.-p. (2011). Fostering international brand loyalty through committed and attached relationships. International Business Review 20, 521-534.

Wulandari, F., Djastuti, I., \& Nuryakin. (2017). Reassessment of the Entrepreneurial Motivation among Female Business Owners to Enhance SMEs Business Performance in Indonesia. European Research Studies Journal, Volume XX, Issue 4A, 2017, pp. 18 - 34. 